\title{
The principle of congruity in the analysis of international business
}

\section{cooperation}

\author{
Buckley, P. J. ${ }^{1}$, Cross, $A .^{2}, \&$ De Mattos, $C .^{3}$
}

\author{
${ }^{1}$ Leeds University Business School, University of Leeds, LS2 9JT, UK. \\ ${ }^{2}$ International Business School Suzhou (IBSS), Xi'an Jiaotong-Liverpool University (XJTLU), Suzhou, \\ 215123, China. \\ ${ }^{3}$ Manchester Business School, University of Manchester, Manchester, M15 6PB, UK
}

This is a pre-print (i.e. pre-refereeing final draft \& non-publisher's) document. Please cite the article as:

Buckley, P. J., Cross, A., \& De Mattos, C. (2015). The Principle of Congruity in the Analysis of International Business Cooperation. International Business Review, 24(6), 1048-1060.

(DOI: http://dx.doi.org/10.1016/j.ibusrev.2015.04.005)

(available: https://www.escholar.manchester.ac.uk/jrul/item/?pid=uk-ac-man-scw:175678).

\begin{abstract}
This study investigates an under-researched topic: individual-to-individual or team-to-team interactions during the alliance pre-formation phase. We develop a general theory based on the principle of congruity for understanding the micro-dynamics of the alliance formation process. The attitudes of each party in an alliance towards their prospective partner depend on the level of mismatch between their initial evaluations of the contributions of each partner, and on their wish intensity and speed to reach congruity. The impact of different managerial cultural backgrounds (special theory) and mind-sets (special theory application) are theorized. Further applications are considered and all are presented as testable propositions.
\end{abstract}

Keywords: Alliances and Joint Ventures, Strategic Alliances in Emerging Markets, Negotiation and Bargaining Procedures, congruity theory, managerial expectations, crosscultural behavior. 


\section{The principle of congruity in the analysis of international business}

\section{cooperation}

\section{Introduction}

Efforts to understand individual-to-individual or team-to-team interactions during the final alliance pre-formation phase are scarce. Besides game theory (e.g., Parkhe, 1993; Seale, Arend, \& Phelan, 2006), a few attempts to further the theoretical understanding of the microdynamics of the process of forming alliances have been reported in the literature, such as theoretical models regarding the development of trust (see Bhattacharya, Devinney, \& Pillutla, 1998; Fulmer \& Gelfand, 2012; Jones \& George, 1998; Kim, Dirks, \& Cooper, 2009; Zaheer, McEvily, \& Perrone, 1998). To date most alliance theories focus on the antecedents and consequences of alliance formation. Furthermore, calls for furthering understanding of the micro-aspects of intergroup interaction have been made in recent years (e.g., Ferrin, Bligh, \& Kohles, 2008; Song, 2009).

In order to address these gaps, we offer an application of the principle of congruity to alliance formation. The principle of congruity (Osgood \& Tannenbaum, 1955) proposes that evaluations or re-evaluations of objects by an individual tend to seek congruity with that individual's frame of reference. Subjective valuation differences have also been identified in other business contexts and models attempting to make compatible these subjective views have been put forward (e.g., Weingartner \& Gavish, 1993). The exploration of alternative actions to forming a partnership is likely to increase the negotiating power of the actor (Malhotra \& Gino, 2011), which in our case could mean higher disappointment with an evaluation from the other party in an alliance. In general, parties that develop a positive atmosphere or good rapport with each other are more likely to reach a mutually satisfying outcome (Jap, Robertson, \& Hamilton, 2011). It has been also suggested that understanding the other party's frame of reference as well as using messages consisting of informational or 
relational content may help to establish a positive atmosphere (Chung, Sternquist, \& Chen, 2006; Srivastava \& Chakravarti, 2009). This closely parallels the ideas of Buckley and Casson (1988), who suggest 'mutual forbearance' as the key to success in joint ventures. We organise this conceptual study into three stages. First, we develop a general theory based on the principle of congruity, and a reverse interpretation of that principle, extended to the case of alliance formation. Second, we develop a special theory considering the impact of cultural differences between the parties. Third, we present an application of the special theory - the case of different mind-sets between managers/entrepreneurs of developed countries and those from emerging economies. This novel extension of the above theory to the context of alliance formation adds to the understanding of the micro-dynamics of interactions between individuals (or between teams).

The use of alliance-based cross-border strategies has intensified in recent years in many business sectors (e.g., Gulati, Lavie, \& Singh, 2009; McDermott \& Corredoira, 2010). However, the success rate of transnational alliances (TAs) in general is low, with figures of 40 per cent and below commonly being cited, although in a few sectors (such as biotechnology) or in firms from a particular country (e.g., Japan) success rates are somewhat higher (see Delios \& Beamish, 2004; Kale \& Singh, 2009; Lunnan \& Haugland, 2008). This is an issue of importance for organizations in general, since the costs of failure can be considerable (Wassmer, Dussauge, \& Planellas, 2010). Moreover, in the case of TAs, it becomes even more crucial when other factors (such as cultural differences) have the potential to increase the likelihood of inter-partner conflict (see Barkema \& Vermeulen, 1997; Marino, Strandholm, Steensma, \& Weaver, 2002). Such situations could, for instance, increase the chances of differing evaluations of the contributions of each partner, which may lead eventually to a negative outcome. A strong relationship between partners should have positive effects on the venture's long-term results (Yan \& Gray, 2001). 
In our study, we propose that the attitude towards the other party is likely to be influenced by the congruence or incongruence of the parties' initial evaluations regarding the prospective contributions of each party (including one's own) to the alliance, and ultimately, this will affect the feasibility of the alliance. In other words, our theoretical framework sheds light on the micro-dynamics of the interaction between mismatched partner-contribution evaluations a potential source of disagreement and dispute during the establishment of the alliance - and the attitudes of managers from the potential partner firms. Drawing on congruity theory, we consider a possible causal link between conflicting partner expectations regarding contributions to the alliance, together with the effect of the attitudes of the managers formalising the alliance towards each other on the one hand, and the likelihood of successful alliance formation on the other. Our theoretical approach assumes that incongruous expectations regarding partners' contributions amongst prospective partners have the potential to impact negatively upon the decision-making process of one or both parties at the time that the alliance is about to be formed and thereafter (cf. Inkpen \& Currall, 2004). It may also have a cumulative effect on managerial judgement regarding the viability of such a partnership. One key factor for establishing and developing a successful TA between unrelated foreign companies is the ability to manage effectively those disputes that might later undermine the commitment of one or more of the parties to the agreement. One approach that should increase our understanding about the formation of effective alliances is to build upon a theory and framework that have originated in other domains. The remainder of the paper is organized as follows. In the next section, we describe the principle of (in)congruity, its assumptions and prior usage. Subsequently, we develop a general theory, based on the principle of congruity, to inform understanding of the microdynamics of prospective partners' interactions in the alliance formation process. We go on to develop a special theory regarding the effect of cultural differences on the process of alliance 
formation. We then illustrate the special theory through a hypothetical illustration that highlights the effect of different mind-sets in the formation of an alliance between a firm from a developed country and a counterpart from an emerging economy (e.g., a BRIC country). Finally, we conclude and propose implications for academics, practitioners, and policy-makers.

\section{Background}

\subsection{Contextual Issues}

A key contextual issue in this study is business alliances between two firms, specifically transnational alliances (TAs). A business alliance between two firms implies a sharing of resources between the partners (Glaister \& Buckley, 1996), and it is usually seen as an expansion strategy involving lower resource commitment, which in turn decreases perceptions of business risks associated with the new venture. The term covers a range of joint activities or commitments (Grant \& Baden-Fuller, 2004).

A number of models have attempted to capture the intricacies of cooperative agreements, and may also be applied to alliances. Models of cooperation have drawn on a range of theoretical frameworks, from game-theory (e.g., Katz, 1986) and economics (e.g., Buckley \& Casson, 1996; Contractor, 1985), resource dependency (e.g., Pfeffer, 1972; Pfeffer \& Nowak, 1976; Van de Ven, 1976) transaction-costs economics (Buckley \& Strange, 2010; Hennart, 1988; Ring \& Van de Ven, 1992; Williamson, 1979, 1991) and strategy views (Fornell, Lorange, \& Roos, 1990; Glaister \& Buckley, 1996; Harrigan, 1988; Kogut, 1991), through to relational exchange (Dhanaraj, Lyles, Steensma, \& Tihanyi, 2004; Kale, Singh, \& Perlmutter, 2000; Zaheer \& Venkatraman, 1995) and knowledge-based perspectives (Grant \& Baden-Fuller, 2004; Hamel, 1991; Kogut, 1988). These theories advance the understanding of alliances by focusing on the antecedents and consequences of alliance formation. 
Nonetheless, they do not shed much light on the micro-level evaluations leading to microlevel tactical decisions just prior to the conclusion of the agreement.

A stream of literature associated with our topic concerns intergroup trust (e.g., Doney, Cannon, \& Mullen, 1998; Lander \& Kooning, 2013; Mayer, Davis, \& Schoorman, 1995; McKnight, Cummings, \& Chervany, 1998; Song, 2009). Our framework identifies microdynamic mechanisms during interactions prior to alliance formation. Those microinteractions may lead ultimately to higher levels of trust between the parties; however, the scope of our framework does not presume initial levels of trust, nor does it attempt to predict outcomes beyond the alliance formation stage. We further argue that our framework differs from those frameworks that focus on trust, because the parties are not at risk (see Mayer et al.'s (1995) definition of risk); the setting of pre-alliance formation assumes a voluntary process in which either party may walk away should they decide to do so (e.g., in the event of no prospective benefits being perceived from the agreement). Therefore, this condition preempts the notion of partner vulnerability and the associated need for trust.

Extant theorizing is less helpful in furthering our understanding of the microdynamics of alliances' final pre-formation stage, when the prospective partners' contributions to the alliance are evaluated, usually at team-to-team or individual-to-individual meetings, and the agreement about who is bringing what to the alliance is concluded. The expectations formed at this stage, which are the basis for the decision-making process, are influenced by different types of bias due, for instance, to the processing of information by each individual/manager involved, as well as by the interaction with other individuals/managers if they are part of a team (Carter, 1971). One of the key factors in establishing and developing a successful TA between unrelated foreign companies is the ability to manage effectively the disputes arising (Fey \& Beamish, 2000) that might later undermine the commitment of one or more of the parties to the agreement. 


\subsection{The principle of (in)congruity}

The principle of congruity (Osgood \& Tannenbaum, 1955) was developed by social psychologists in the 1950s to explore instances of attitude change. Subsequently, it has been applied to or mentioned in the areas of politics (e.g., Brady \& Sniderman, 1985; Kirkpatrick \& McLemore, 1977; Shapiro, 1969) and consumer marketing, particularly in advertising and branding (e.g., Aaker \& Keller, 1990; Olshavsky \& Miller, 1972; Perkins \& Forehand, 2012; Salciuviene, Ghauri, Streder, \& De Mattos, 2010; Zhang, 2010). So far as we know, the present study represents the first application of congruity theory to international business cooperation. We should note here that the principle of congruity refers to individual action and it differs, therefore, from concepts of congruence or congruity at the organization level, usually denoting strategic fit between firms (e.g., Bierly \& Gallagher, 2007).

The essence of congruity theory is that changes in the evaluation of a phenomenon (or concept) by an individual are always in the direction of increased congruity with the existing frame of reference of that individual (Osgood \& Tannenbaum, 1955). In other words, congruity theory predicts that a change in the attitude of one individual or party is dependent upon the degree of congruity between the assertions made by another individual or party and the former individual's frame of reference, as these assertions manifest themselves during interactions between the two. Here, the dependency of one's behavior on the actions or behaviors of others in a negotiation parallels the concept of relational-self (see Gelfand, Major, Raver, Nishii, \& O'Brien, 2006). We may assume causality in two directions. In one direction, say positive causality, individuals will tend to agree with those who hold similar frames of reference expressed by similar views or evaluations of objects or actors. In another direction, say reverse causality, individuals will tend to adjust their frames of reference to compensate for dissimilar views or evaluations of objects or actors held by others. Thus, in the former case congruity is achieved through holding similar views, whereas in the latter 
case (henceforth referred to as reverse interpretation) congruity is achieved by adjusting one's frame of reference to dissimilar views or evaluations regarding objects or actors.

The necessary participation of individuals (i.e., managers or executives) at the concluding stage of alliance agreements (even as part of a team) supports the use of psychology research on individual decision-making processes, such as congruity theory; this, in turn, can be expected to deepen our understanding of the final stage of the allying process. Social interaction among individuals, as well as the context in which these interactions occur, are the basis for the development of any theory in the social sciences (Bales, 1950). Our main purpose here is to hypothesise about a generalised pattern of behavior regarding the conclusion of the alliance agreement.

Some of the general assumptions underlying theories on the psychology of individual decision-making such as congruity theory are as follows:

a) Individuals (alone or as part of a team) will either take or influence decisions or both. In general, observable social phenomena comprise both overt interactions among individuals and the situation or context in which these interactions take place. It may include the self, other individuals and physical objects (Bales, 1950). In particular, we assume that, underlying the interactions that may be observed, there are interactions with the self which are not observable overtly, as are interactions with other individuals or those with objects (Bales 1950). We assume that interactions with the self-influence the decision-making process of individuals or, more specifically in our case, managers.

b) Those decisions will draw on each individual's past experiences or knowledge-base and how each individual respectively processes and employs that information. 
c) Individual and/or team interactions between prospective partners will also generate information that will in turn be fed into each individual's knowledge-base as described above.

d) If an individual is part of a team, his or her influence on the final decision regarding any item will also reflect the hierarchical structure and decision-making rules within the team. For instance, assuming a leadership structure, the attitude of individuals positioned closer to the team's decision-maker will have greater influence relative to individuals who are more distant from the decision-maker. This parallels ideas related to the effects of the homophily principle - ties between individuals brought about by perceived similarities (e.g., McPherson, Smith-Lovin, \& Cook, 2001).

These assumptions lead to areas where current understanding is obscure, such as the dynamic process through which individual decisions are formed and how these influence decisions developed by the team through interactions within its members.

Although our study focuses on the micro-dynamics of interactions in the context of alliance formation, we make assumptions regarding the macro-environment in which these proposed micro-interactions take place, using existing conceptual frameworks. This should clarify the impact of critical macro-environment factors, which may significantly affect the potential testability of the propositions presented later in the paper, on our process model. It should also support the future testability of the model through empirical research. Further research should be able to systematically disentangle the proposed effects and validate the propositions outlined later in the paper. Such prior circumstances may mold the frames of reference used in managerial decision-making, thus influencing both process and outcome, and should highlight the boundary conditions and possible limitations of our proposed conceptual framework. 
The context of our study considers a dyadic (two-party) alliance context rather than one associated with an alliance network (Koka \& Prescott, 2002) or multi-party alliance (i.e. an alliance constellation) (Das \& Teng, 2002). Within this context, we shall clarify our assumptions regarding the firms' social embeddedness (Hagedoorn, 2006), status similarity (Chung, Singh, \& Lee, 2000; Podolny, 1993, 1994), the amount of inter-firm social capital (Inkpen \& Tsang, 2005; Koka \& Prescott, 2002), inter-relationships between organizational activities such as innovation (Stuart, 1998), and the existence of prior ties (Gulati, 1995a, 1995b).

First, considering the three levels of embeddedness of a firm as proposed by Hagedoorn (2006), and in order to keep our process framework simple, we assume with regard to environmental country-specific and industry-specific factors (i.e. environmental embeddedness) high complexity and uncertainty arising from local business practices (such as those in large emerging markets) and high-technology sector constraints and uncertainties (such as those in biotechnology sectors). Relative to the history of the parties regarding alliance attempts, (i.e., interorganisational embeddedness) as well as personal network links between individuals across organizations (i.e., dyadic embeddedness), we assume, for simplicity, the absence of any prior contact in both cases. These assumptions will adequately represent the case of firms from a developed country approaching emerging-economy counterparts in a high-technology sector for the first time.

The relative status of prospective partners is another factor that may impact alliance formation prospects. Chung et al. (2000) suggest that the relative status of prospective partners is usually assessed prior to alliance-formation attempts. The perceived quality of a firm's products is a measure of the status of such firms (Podolny, 1993). The simplest assumption in this case, and the one we adopt, will be of equal status between partners. One may argue, however, that status will depend on the social dynamics of a specific business 
environment; for instance, a local firm may have high status locally, without being known in broader contexts (e.g. the global environment). We therefore assume that whatever differences may exist in status between two firms, this will be considered as part of the potential contributions firms may offer to, or aim to retrieve as a benefit from, the partnership.

A further factor that may affect efforts to create and alliance concerns the amount of inter-firm social capital, which emphasizes the benefits harvested through previous social links (Portes, 1998), highlighting rational individual decision-making and motivation within the constraints of a social environment (Coleman, 1988). Benefits accrued through social links, such as access to relevant information, may facilitate the establishment of an alliance, particularly if they support the process of generating or strengthening trust, concomitantly curbing opportunism (Inkpen \& Tsang, 2005). Social capital associated with an alliance network may support, for instance, the selection of appropriate partners, skilled in relevant capabilities and resources (Gulati, 1995a); it should also positively affect knowledge transfer between partners after the alliance is established (Koka \& Prescott, 2002). The perceived mutual benefits to be realized through sharing resources may in turn strengthen the positive drive towards alliance formation (Gulati, 1995a).

In this study, each area of knowledge potentially available through an alliance, such as knowledge on alliance or network management practices or novel technology (Inkpen \& Tsang, 2005), may be seen as a contribution from one of the partners to the alliance and should generate expectations regarding its value and impact. Aiming to simplify our model, we assume that intra-firm social capital is non-existent, or in the initial phases of development - in other words, a situation characterized by an abundance of 'structural holes' (Burt, 1997), which increases the potential opportunities for establishing value-adding intrafirm links. We further assume that the interacting firms are aware of the limitations that each 
may carry into the alliance and the benefits they may achieve by accessing their partner's capabilities and resources through the alliance. Such arguments are popular among resourcedependence theorists. If each opportunity for beneficial resource-sharing is seen as a potential contribution to the alliance, what differs is the importance or value assigned to each potential contribution. This is the gap investigated in this study.

In addition, the similarity of firms' technological bases should affect alliance formation positively (Mowery, Oxley, \& Silverman, 1998), as there should be a stronger mutual understanding of the technology to be shared through alliance (Stuart, 1998). Moreover, not only may technology be a potential contribution, but the firm's capacity to absorb a particular technology (Cohen \& Levinthal, 1990) may be seen as a contribution to the ultimate goal of forming an effective alliance. Our assumption here is that both knowledge and the capacity to absorb it exist respectively at specified levels, and they are perceived as prospective contributions and considered as such in our process framework.

Another factor that may influence alliance formation is the level of similarity in inter-firm status (Podolny, 1994; Chung et al., 2000; Shipilov, Li, \& Greve, 2011), as well as a firm’s accumulation of status through links with better-known players (Shipilov \& Li, 2008). Current understanding suggests that uncertain environments tend to be associated with alliance formation between firms of similar status, although this trend may only be observed if the level of economic activity in a particular market is in decline (Collet \& Philippe, 2014). Considering international alliances, it is challenging to ascertain a measure of a firm's status because of the contextual importance of local versus international standing. However, it would seem reasonable to assume that a firm will only contemplate firms above a certain status level as prospective matches, even if only considering the local context. For instance, a foreign partner will most likely consider allying with one of the top local firms, even though they may not have any significant international standing. 
Finally, a history of previous alliances will also tend to affect collaboration prospects positively (Gulati, 1995b). This seems to be the case when such previous ties are conducted and concluded successfully and without major conflict. Cases where a firm is removed from consideration as a prospective partner due to conflict generated in previous interactions have not been investigated to our knowledge, although such action might reasonably be expected. For simplification, our assumption here is that there has been no business interaction prior to the attempt that serves as context to this study. Although we exclude here firms that have had previous ties, we acknowledge that some past connections of a social rather than business nature may exist, even if such connections were generated through the business-deal initiative under scrutiny. We might expect that the non-existence of prior ties could work as a deeper underlying factor regarding the level of mismatch in critical evaluation of the contributions of each partner, the magnitude and scope of the wish intensity and the speed of searching congruence.

In order to further simplify our model, we assume that each party follows a leader or decision-maker whose attitudes and opinions drive the sequence of interactions towards a possible agreement. By doing this, we focus on one individual's (the leader) decision-making process rather than that of the team. One implication of congruity theory is that individuals are more likely to place greater importance or value on people who hold beliefs that are more congruent with their own belief system or frame of reference. These assumptions may be made more complex at a later stage of the theory-building process.

\section{Model Development}

\subsection{A general theory: Application of congruity theory to alliance formation}

In this section we first extend congruity theory to alliance formation using a reverse interpretation. We demonstrate our proposition by making a small number of assumptions in order to simplify the model and to allow us to focus on the essence of our interpretation of the 
principle of congruity. Finally, we include possible mediator variables and derive a general theory. We look at the interaction between managers considering their valuation of the contributions of each partner and their attitude towards the other party. We propose that, ceteris paribus, different sequences of micro-interactions may lead to diverse (even opposing) likely outcomes. Our proposed approach using congruity theory addresses the knowledge gap regarding individual-to-individual or team-to-team interactions in the concluding stages of alliance pre-formation, when the final agreement regarding the partners' contributions to the alliance is reached. In other words, the congruity approach allows us to predict the micro-dynamics of the interaction of managers prior to finalising an alliance agreement.

Analysis using congruity theory can be extended to the case of dyadic (two-party) business alliance formation by considering the attitudes of both partners towards each other, together with their evaluations of the contributions they expect to bring to the alliance, as well as of those contributions they expect from the potential alliance partner. The attitude of one prospective alliance Partner (P1) (i.e. an individual or team within that firm) towards another prospective alliance Partner (P2) is dependent on the cumulative effect of the (in)congruity of P1's attitudes towards a number of objects of judgement and P2's attitudes towards the same objects. Thus, we may define the initial Frame of Reference of P1 (FR1) in the context of a dyadic alliance as the initial attitude of P1 towards P2 $\left(\mathrm{A}_{1,2}\right)$, together with the original attitude (or evaluation) $(\mathrm{t}=0)$ of $\mathrm{P} 1$ towards the $\mathrm{k}$ potential contributions $\left(\mathrm{C}_{\mathrm{k}}\right)$ to the alliance by $\mathrm{P} 2$, plus the original attitude $(\mathrm{t}=0)$ of $\mathrm{P} 1$ towards their own $\mathrm{k}$ ' potential contributions $\left(\mathrm{C}_{\mathrm{k}}\right.$ ) to the alliance. Thus, FR1 comprises $\mathrm{A}_{1,2}$ as well as $\mathrm{A}_{\mathrm{t}=0, \mathrm{i}=1, \mathrm{Ck}, \mathrm{j}}$ (where $\mathrm{A}$ stands for attitude; " $\mathrm{t}=0$ " for time " 0 " or initial attitude; " $\mathrm{i}=1$ " for $\mathrm{P} 1$; and " $\mathrm{j}$ " takes values of "1" - relative to P1, and "2" - relative to P2) (see Figure 1). We also define the congruity of attitudes between $\mathrm{P} 1$ and $\mathrm{P} 2$ towards the contribution $\mathrm{k}$ of $\mathrm{P} 2\left(\mathrm{CA}_{\mathrm{Ck}, 2}\right)$ and the contribution $\mathrm{k}$ ' 
of P1 $\left(\mathrm{CA}_{\mathrm{Ck}^{\prime}, 1}\right)$. The Total Attitude Congruency for a two-party alliance will be a function of the added effects of $\mathrm{CA}_{\mathrm{Ck}^{\prime}, 1}$ and $\mathrm{CA}_{\mathrm{Ck}, 2}$, that is, $\mathrm{CA}_{\text {total }}=\mathrm{f}\left(\mathrm{CA}_{\mathrm{Ck}^{\prime}, 1} ; \mathrm{CA}_{\mathrm{Ck}, 2}\right)$ or, assuming a cumulative linear effect, $\mathrm{CA}_{\text {total }}=\sum_{\mathrm{k}} \mathrm{CAc} \mathrm{c}_{\mathrm{k}, 1}+\sum_{\mathrm{k}} \mathrm{CAc}_{\mathrm{k}, 2}$. In other words, the attitude of P1 towards $\mathrm{P} 2$ at a certain point in time $(\mathrm{t}=1)$ depends on the initial attitude of $\mathrm{P} 1$ towards $\mathrm{P} 2$ (i.e., $\mathrm{t}=0$ ) plus the effect of the (in)congruence of various attitudes (i.e., based on subjective evaluations) between P1 and P2 towards items or features linked to the deal - for simplicity in our case the prospective contributions of each partner. This can be expressed as: $\mathrm{A}_{\mathrm{t}=1,1,2}=\mathrm{A}_{\mathrm{t}=0,1,2}+\mathrm{CA}_{\text {total }}$, where $\mathrm{CA}_{\text {total }}=\sum_{\mathrm{k}} \mathrm{CAc}_{\mathrm{k}, 1}+\sum_{\mathrm{k}} \mathrm{CAc}_{\mathrm{k}, 2}$, where: $\mathrm{A}_{\mathrm{t}=1,1,2}$ is the attitude of $\mathrm{P} 1$ towards $\mathrm{P} 2$ at time $\mathrm{t}=1$, and $\mathrm{A}_{\mathrm{t}=0,1,2}$ is the attitude of $\mathrm{P} 1$ towards $\mathrm{P} 2$ at time $\mathrm{t}=0$, and $\mathrm{CA}_{\text {total }}$ is the overall congruence between the attitudes of $\mathrm{P} 1\left(\mathrm{~A}_{\mathrm{Ck}, 1}\right)$ and $\mathrm{P} 2\left(\mathrm{~A}_{\mathrm{Ck}, 2}\right)$ regarding the contributions of each partner $\left(\mathrm{C}_{\mathrm{k}}\right.$, and $\left.\mathrm{C}_{\mathrm{k}}\right)$ and assuming a cumulative linear effect.

Insert Figure 1 about here

Following the principle of congruity, these changes of attitude may be generated by the degree of conformity or match between P1's initial expectations regarding each partner's contribution and P2's expectations, regarding, respectively, each of those contributions. A simplified demonstration follows.

Let us further assume that the initial attitude of $\mathrm{P} 1$ towards $\mathrm{P} 2$ is neutral $\left(\mathrm{A}_{1,2}=0\right)$ - a realistic assumption when firms attempt to establish an alliance for the first time. Should P1 possess any negative information about $\mathrm{P} 2, \mathrm{P} 1$ will not proceed with the arrangement. Consider the possible attitudes of both partners regarding contribution 1 of $\mathrm{P} 2\left(\mathrm{C}_{1,2}\right)$. Let us further consider only two possible attitudes favourable or positive $(+1)$, and indifferent or 
neutral (0). If P1's attitude towards P2 is initially neutral, we can focus our attention on the congruence of attitudes between P1 and P2 towards the alliance partners' contributions. Both partners could potentially bring to the alliance ' $\mathrm{k}$ ' different contributions and each partner would have an initial expectation considering each respective contribution by each partner.

Next, we focus attention on the original attitudes towards the contributions of each partner. Table 1 illustrates possible congruity or incongruity of expectations between partners regarding Contribution 1 of $\mathrm{P} 2\left(\mathrm{C}_{1,2}\right)$, as well as the resultant levels of congruity or incongruity. Based on the principle of congruity, we would expect that instances where there is congruence regarding the indifferent evaluation of $\mathrm{C}_{1,2}$ (lower right cell) will not cause any change in P1's frame of reference. Instances where there is congruity about favourable perspectives (upper left cell) should affect positively P2's image in P1's frame of reference. The instances of incongruity (lower left and upper right cells) indicate conflicting perceptions or evaluations and should influence negatively P1's perception of P2 within P1's frame of reference. This procedure can be repeated for each of the k contributions of Partner 2 $\left(\mathrm{CAc}_{\mathrm{k}, 2}\right)$, and, assuming a cumulative linear effect, will result in a Total Attitude (In)Congruence of $\mathrm{CA}_{\text {total }}=\sum_{\mathrm{k}} \mathrm{CAc}_{\mathrm{k}, 2}$.

Insert Table 1 about here

According to the principle of congruity, the tendency is to reach maximum congruity with one's frame of reference. Taking as an example the situation indicated by the lower left cell (i.e., one of the incongruous instances), P2's assertion regarding $\mathrm{C}_{1,2}$ conflicts with P1's initial frame of reference. Assuming that attitudes towards $\mathrm{C}_{1,2}$ do not change, then P1's 
evaluation of P2 will tend to become more negative in order to reach congruity (see Figure 2 for $\mathrm{t}=1$ ). A negative (rather than neutral) attitude towards $\mathrm{P} 2$ counter-balances the relatively negative evaluation of $\mathrm{P} 2$ regarding $\mathrm{C}_{1,2}$. Or, considering another direction for the effect, a prospective partner (evaluator) who is perceived negatively is expected to make (relatively) negative evaluations of the objects under scrutiny, in our case contribution $\mathrm{C}_{1,2}$, and thus congruity is maintained.

If similar evaluations are put forward when $\mathrm{P} 1$ is examining $\mathrm{C}_{2,2}$, then $\mathrm{P} 1$ 's perception of P2 will become even more negative. We could repeat this for all ' $k$ ' contributions of each partner. It seems reasonable to expect that the more incongruous are the evaluations of P2 regarding each of his own $\mathrm{k}$ contributions $\left(\mathrm{C}_{\mathrm{k}, 2}\right)$, the less likely it is that the conclusion of an alliance will lead to a successful outcome. The magnitude of this effect may be culturedependent as we point out in the next section.

Extending this thinking to the formation of alliances between independent firms, it can be argued that incongruence concerning the contributions to a transnational alliance expected by the respective partners will influence negatively the attitudes of managers as they exchange information during the early phases of discussion and reaching agreement. Following De Dreu, Weingart and Kwon (2000), this negative attitude may then affect unfavourably the atmosphere in which discussions are held and the ability for a mutually acceptable agreement to be concluded, to the detriment of current and future relationships and dealings between the firms.

Insert Figure 2 about here 
Thus, based on the above discussion, a theoretical link between different perceptions regarding the potential contributions of partners of an alliance and the chances of successful alliance formation can be established.

If we include moderator functions or variables, we arrive at a general proposition as follows.

$$
\mathrm{A}_{\mathrm{t}=1,1,2}=\mathrm{A}_{\mathrm{t}=0,1,2}+\mathrm{f}_{\mathrm{a}}\left(\mathrm{CA}_{\text {total }}, \sum_{\mathrm{m}} \mathrm{M}_{\mathrm{m}}\right)
$$

Where:

$\mathrm{A}_{\mathrm{t}=1,1,2}$ is the attitude of $\mathrm{P} 1$ towards $\mathrm{P} 2$ at time $\mathrm{t}=1$,

$\mathrm{A}_{\mathrm{t}=0,1,2}$ is the attitude of $\mathrm{P} 1$ towards $\mathrm{P} 2$ at time $\mathrm{t}=0$,

$\mathrm{f}_{\mathrm{a}}=$ function representing the congruity and the adaptation effects;

$\mathrm{CA}_{\text {total }}=\sum_{\mathrm{k}} \mathrm{CAc}_{\mathrm{k}^{\prime}, 1}+\sum_{\mathrm{k}}, \mathrm{CAc}_{\mathrm{k}, 2}$, representing the cumulative congruity or incongruity regarding the contributions of each partner. $\mathrm{CA}_{\text {total }}$ is the overall congruence between the Attitudes of $\mathrm{P} 1\left(\mathrm{~A}_{\mathrm{Ck}, 1}\right)$ and $\mathrm{P} 2\left(\mathrm{~A}_{\mathrm{Ck}, 2}\right)$ regarding the contributions of each partner $\left(\mathrm{C}_{\mathrm{k}}\right.$, and $\left.\mathrm{C}_{\mathrm{k}}\right)$ and assuming a cumulative linear effect;

$\mathrm{M}_{\mathrm{m}}(\mathrm{m}=1,2,3, \ldots, \mathrm{r})$ refer to ' $\mathrm{r}$ ' moderator-variables that will impact on the adaptation of the congruity function, such as, cultural differences among parties, different mind-sets, and different genders, or their combined effects.

In general, we could say that the attitude of one prospective partner (P1) (i.e., an individual or team within that firm) towards another prospective alliance partner (P2) is dependent on: (a) the initial attitude of $\mathrm{P} 1$ towards $\mathrm{P} 2$; (b) on the total (in)congruity $\left(\mathrm{CA}_{\text {total }}\right)$ or the (in)congruity of P1's attitudes (evaluations) towards a number of objects of judgment (e.g., the partners' contributions) and P2's attitudes (evaluations) towards the same objects; and (c) the effect of the mediator / moderator functions or variables on the adaptation of the individual's behavior as a result of the total (in)congruity $\left(\mathrm{CA}_{\mathrm{total}}\right)$. 


\subsection{A Special Theory: The impact of cultural differences on the application of congruity theory to alliance formation}

In this section we consider the effect that cultural differences may have on the general model. The literature indicates that culture may influence face-to-face interactions in a number of ways. Cultural dimensions have been found to impact managers' preferences and behavior towards business partners (Lee, Shenkar, \& Li, 2008; Marshall \& Boush, 2001), in particular during the negotiation process (e.g., Graham, Evenko, \& Rajan, 1992; Lee, Yang, \& Graham, 2006).

An illustration of the importance of culture as an important factor on international interfirm deals regards the acquisition of Volvo Cars by the Chinese car manufacturer Geely. Or in the words of Geely's chairman Mr Li Shufu regarding the post-acquisition process: "[The biggest lesson in the first year after buying Volvo is that] you really need to study and understand and respect the culture of the company and the culture of the nation and through discussion form a consensus.” (Waldmeir, 2011).

It has been suggested that cross-cultural negotiations will tend to achieve lower joint gains than intra-cultural negotiations (Brett \& Okumura, 1998). Moreover, different cultures may support seemingly opposite negotiation approaches, each leading to optimum outcomes under given circumstances (Graham et al., 1992). In addition, cultural differences seem to have a stronger negative effect on trust building when interacting with new business contacts as the partners do not know each other well (Marshall \& Boush, 2001).

Difficulties to go across different corporate cultures may be another illustration, or in the words of a senior financial analysis (Thomas Caldwell, Caldwell Financial, Toronto) while analysing the low performance and subsequent acquisition of Merrill Lynch by the Bank of America under Mr John Thain by the end of 2008: "[Merrill Lynch is] a unique culture. If 
you come in as an outsider, you'd better be paying attention, because it's a tough game." (Farrell and Sender, 2009).

Lander and Kooning (2013) suggest that the development of trust is based concomitantly on a number of domains including the personal sphere and the interaction process. Another related finding refers to the long-term orientation of Japanese retailers as an antecedent to trust and satisfaction with suppliers and how, as a consequence, Japanese retailers put more effort into resolving their differences with suppliers than searching for new ones (Chung et al., 2006), which may be seen as culture-specific behavior. Suggestions for deepening the understanding of the negotiation process, particularly in international cross-cultural settings, have been made (e.g., Brett \& Okumura, 1998). More recently, the importance of understanding the motivations and constraints or alternatives of the other party has been highlighted (Malhotra, 2013). Furthermore, a number of potential sources of conflict have been identified by looking at cross-cultural business interactions as well as through comparisons across cultures. Such sources of conflict range from differences on culturally-derived or culturally-embedded values (Chen, Mannix, \& Okumura, 2003; Molinsky, 2007; Tinsley \& Pillutla, 1998; Tinsley, 2001) and business practices or negotiation approaches (Adler, Brahm, \& Graham, 1992; Graham, 1985; Liu, Friedman, \& Hong, 2012), to cognitive styles (Abramson, Lane, Nagai, \& Takagi, 1993; Adler, Doktor, \& Redding, 1986; Redding, 1980) and interaction behaviors (Adair, Weingart, \& Brett, 2007; Adler et al., 1992; Lee et al., 2006; Liu, Chua, \& Stahl, 2010).

If we compare the possible effect of a collectivistic versus individualistic culture, it seems reasonable to expect that members of collectivist cultures will tend to seek harmony faster than members of individualist cultures, as it is part of their cultural behavior to place collective concerns above individual ones (Kim, Park, \& Suzuki, 1990; Marcus \& Le, 2013). This may be interpreted as affecting the speed and strength of a desire to return to congruity. 
In other words, a member of a collectivistic culture can be expected to desire a faster return to congruity, compared to a member of an individualistic culture. Hence, the strength to comply with the principle of congruity, is culturally dependent. The extent of incongruity is first perceived by the party or individual and, subsequently, there is time for adjustment to occur. The speed of adjustment will also be culturally dependent.

In our context, cross-cultural differences can be expected to affect the micro-dynamic stages of a sequence of interactions and, hence, the predicted outcome of the alliance formation process. More specifically, both the strength of the intention to reach congruity and the speed to take action towards that objective can be expected to be culturally dependent.

Using the general formulation from the previous section - see Formula (1) - and setting the moderator function $\mathrm{M}_{1}=\mathrm{C}_{\mathrm{r}}$, we have:

$$
\mathrm{A}_{\mathrm{t}=1,1,2}=\mathrm{A}_{\mathrm{t}=0,1,2}+\mathrm{f}_{\mathrm{a}}\left(\mathrm{CA}_{\text {total }}, \mathrm{C}_{\mathrm{r}}\right)
$$

where $C_{r}$ represents cultural differences described by a cultural vector $C_{r}=g\left(C_{r 1}, C_{r 2}, \ldots, C_{r n}\right)$, with $\mathrm{n}$ as the number of cultural dimensions under consideration. $\mathrm{C}_{\mathrm{r}}$ affects both the magnitude and the speed of the incongruity adaptation effect.

It should be noted that other special theories could be derived from the general theory, for example, the effect of the gender of the participants on compliance with the principle of congruity.

\subsection{An Application of the Special Theory: contrasting mind-sets of managers of developed countries and their counterparts in large emerging economies}

Next we illustrate an application of the special theory (see previous Section) to the case of alliance formation between managers of diverse mind-sets, that is, managers of firms from Developed Countries (DCs) and those of firms from Large Emerging Markets (LEMs). In this context, one potential source of disagreement and dispute concerns the contributions to the transnational alliance (TA) expected by and of the partners (Stopford \& Wells, 1972). The 
impact of divergent expectations due to diverse objectives or mind-sets has been illustrated in the context of entrepreneurs and venture capital managers (Chua \& Woodward, 1993). Underpinning this idea is the notion that early identification of misunderstandings concerning the potential contributions of the partner can increase the ability of managers to intervene and resolve any mistrust that might arise, through better communication of their respective viewpoints and objectives and through the development of joint solutions. Yan and Gray (2001) suggest that the bargaining power of the parties is determined not only by the partners' contributions but also by the context of the negotiation and the strength of the relationship. It has also been suggested that the evaluation of the other party's benefits may be linked not just to the relationship situation, but to the negotiators' personality characteristics too (Corfman \& Lehmann, 1993).

Three important issues in international business studies provide the context for this application of the special theory. The first concerns the low success rates of TAs, the second the growing importance of LEMs in the global arena (De Mattos, Burgess, \& Shaw, 2013), and the third the importance of commercial biotechnology for both governments and the private sector. Moreover, LEMs and high-technology sectors illustrate respectively environments of high uncertainty and high complexity. We suggest that the rapidly-changing conditions of these environments may affect the judgement of managers and therefore their mind-set. LEMs such as Brazil, China, India, Turkey, and Mexico are quickly acquiring greater prominence in the global economy (e.g., NIC 2008; O'Neill \& Stupnytska, 2009; UNCTAD, 2009, 2010; Wilson, Kelston, \& Ahmed, 2010) and have consequently attracted considerable scholarly attention (e.g., Eichengreen, Gupta, \& Kumar, 2010; Lu, Zhou, Bruton, \& Li, 2010; Kotabe, Parente, \& Murray, 2007; Meyer, Estrin, Bhaumik, \& Peng, 2009; Muller \& Kolk, 2010; Ramamurti \& Singh, 2009; Trevino \& Mixon Jr. 2004; Wasti, 2008). This prominence is expected to grow more rapidly over the coming years as firms 
strive to secure first-mover advantages in LEMs, and benefit from scale economies, location advantages and other effects. In addition, contrary to some widely-held assumptions in the literature, business opportunities in LEMs are not restricted to low- and medium-technology deals. Indeed, LEM-based firms have grown their presence in markets for technologyintensive products and services (Santos, 2007; UNCTAD, 2010), particularly those from Latin America and the transition economies (see Filatotchev, Liu, Buck, \& Wright, 2009; Murray, Kotabe, \& Zhou, 2005; Kotabe et al., 2007; Kotabe, Teegen, Aulakh, Coutinho de Arruda, Santillán-Salgado, \& Greene, 2000; Siqueira \& Bruton, 2010).

As a result, business deals between firms from LEMs and their counterparts in developed countries have increased. Recently, MNEs from LEMs have invested into developed countries to source technology and other strategic assets (UNCTAD, 2010). LEMs differ from other developing economies in that they generally possess a reasonably good industrial infrastructure and have fairly advanced scientific capabilities, even if these are limited to universities and research centers, and are generally unavailable on a commercial scale. However, LEMs share with other developing countries certain market inefficiencies, such as investment-unfriendly regulatory regimes and taxation systems, as well as policies which often stifle local entrepreneurship (Dinello \& Shaoguang, 2009; Gupta, Hasan, \& Kumar, 2010; World Bank, 2010). Within this context, the ability of firms - be they LEM firms looking to acquire technology and other assets from developed-country partners, or developed-country firms seeking to tap into the opportunities presented by LEMs - to devise mechanisms and tools that help potential sources of conflict to be identified at an early stage of TA formation would go a long way towards improving the probability of a successful alliance. Based on our review of the literature, we can identify four areas of potential incongruity regarding the perceptions of different groups of managers concerning the prospective contributions of the developed country partner and, thus, potential sources of 
conflict between alliance partners. These incongruities relate primarily to the resourceseeking strategies of the respective firms, namely access to capital, advanced technology, technical personnel, and supplementary product lines.

\subsubsection{Transnational alliance partner contributions}

One application of the principle of congruity is to the case of dyadic (two-party) alliances, in order to establish in theory a causal link between congruence of expectations (or evaluations) regarding the contributions from a prospective partner to the alliance and the likelihood of alliance formation.

From our discussion of the literature, we can extract two main ideas. First, managers contemplating a transnational alliance have certain prior expectations of their potential partners, especially concerning their respective contributions. Second, these expectations may differ amongst alliance partners, or, expressed another way, incongruity may be present. Should this prove to be the case, conflict is likely to ensue and the risk of failure may be heightened. For the reasons explained above, because of respective institutional and environmental differences it is likely that incongruous expectations will be observed between developed-country firms and those from emerging markets. This indicates the need for

managers in such situations to be more cognisant of possible mismatches of expectations during the alliance formation process and to be better prepared to deal with them as and when they arise.

There is now a substantial literature on how firms select potential partners on the basis of the contribution that the partner can bring to the TA. A review of this literature has helped us to identify those potential contributions to a TA which, as the discussions above indicate, have the potential to provide a source of incongruity between the respective managers of the partner firms. The importance of the contributions of potential partners to an alliance will depend on the ongoing strategy of the firms involved, and on the availability of each factor 
under examination, including the internal resources of participating firms. Dong, Buckley, and Mirza (1997) draw attention to differences in the perceived importance of contributions between culturally-different foreign collaborators. We can infer from congruity theory thinking that it is likely that any manager involved in a potential alliance will have a frame of reference (or mind-set) against which he or she will assess the potential contributions of a prospective TA partner, possibly allocating objective or subjective weightings to those contributions as they are evaluated (Cavusgil, Ghauri, \& Akcal, 2013). However, prior literature identifying precisely what these contributions are likely to be is somewhat limited. Only a limited number of studies provide detailed lists of potential contributions, and only few of those consider contributions of developed-country partners (e.g., Beamish, 1987; De Mattos, Sanderson, \& Ghauri, 2002; Dong et al., 1997; Dong, \& Glaister, 2006; Erden, 1997; Geringer, 1991; Glaister \& Buckley, 1997; , Raveed \& Renforth 1983; Stopford \& Wells, 1972; Wright, Filatotchev, Buck, \& Bishop, 2002). Within this literature there is little consensus A number of other studies do consider partner contributions, but without it being their main purpose or focus (see Blodgett, 1991; Chen, Park, \& Newburry, 2009; Fagre \& Wells, 1982).

Having established that contributions from TA partners, in general, are expected to influence the likelihood of successful formation as well as the continuance of a transnational alliance, in the next section we turn our attention to specific contributions and the potential incongruity of perceptions between TA partners regarding those contributions and hence their potential to cause conflict and derail the TA formation process.

Considering that the general theory (1) and the special theory focusing on cultural differences (2), and defining $C_{r}=g\left(C_{r 1}\right)$, i.e., the cultural vector $\left(C_{r}\right)$ is dependent on just one dimension $\left(\mathrm{C}_{\mathrm{r} 1}\right)$, which represents the different mind-sets of managers from DCs and their counterparts in LEMs, we have: 


$$
A_{t=1,1,2}=A_{t=0,1,2}+f_{a}\left(C_{\text {total }}, C_{r 1}\right)
$$

In this special case, the Attitude of $\mathrm{P} 1$ towards $\mathrm{P} 2$ at time $\mathrm{t}=1\left(\mathrm{~A}_{\mathrm{t}=1,1,2}\right)$ is the Attitude of $\mathrm{P} 1$ towards $\mathrm{P} 2$ at time $\mathrm{t}=0\left(\mathrm{~A}_{\mathrm{t}=0,1,2}\right)$ plus the effect of the cumulative congruity or incongruity, which in turn is affected by the different mind-sets $\left(f_{a}\right)$ in what relates to determining setting the magnitude and speed of the wish to conform with the principle of congruity. Further specific propositions could be derived from variants of the special theory of cultural differences - for instance, those based on the various dimensions of culture in Hofstede's work (Hofstede, 1980). Examples include a proposition that the different speed or intensity of compliance with the principle of congruity depends on the degree of individualism/collectivism of the individuals or teams interacting in the joint venture. Similarly it could be proposed that compliance speed or intensity will vary according to the cultural distance (psychic distance) between the participants.

\section{Propositions}

Our approach provides a set of testable propositions at general, special and specific levels. It enhances the theoretical understanding of behavior in joint ventures and is complementary to the approach based on 'mutual forbearance' given by Buckley and Casson (1988). Indeed, the two approaches together suggest a means of achieving success in collaborative ventures based on a commitment to understanding the culture and mind-set of partners and maximising congruity in order to increase the commitment of all partners to the venture. Such an approach can reduce the ex $\underline{\text { ante }}$ risk of (international) inter-cultural joint ventures.

We develop below a number of propositions to guide the necessary empirical testing. The propositions derive from the general theory as well as from further specifications of the special theory. Regarding the former, propositions may be raised regarding moderators $\left(\mathrm{M}_{\mathrm{i}}\right)$ different from those already covered by the special theory (i.e., culture) or the application of 
the special theory (i.e., mind-set). An example of such a proposition drawing on the general theory is a special theory on the effect of gender differences.

Indirect recognition that there may be gender-related factors affecting women entrepreneurs are indicated by the European Commission initiatives and the 2012 report (European Commission, 2012): "The aim [of this report] is to follow the development of the number of women entrepreneurs and of gender segregated statistics and thereby make the contribution of women entrepreneurs to society more visible." The report carries on by pointing out the problems in identifying the contributions of female entrepreneurs (and by implication, female managers) because many countries do not provide business-related statistics differentiated by gender.

Proposition 1: Considering a sequence of interactions and individuals of similar cultural background, the wish intensity as well as the speed to reach congruity following incongruent initial valuations of prospective partners' contributions to an alliance will be gender-dependent.

The above proposition may give rise to a number of hypotheses that will consider different outcomes when considering, for instance, different cultural dimensions.

Or using the general theory, refer to formula (1), and defining $\sum_{m} M_{m}=M_{g}$, we have:

$$
A_{t=1,1,2}=A_{t=0,1,2}+f_{a}\left(C A_{\text {total }}, M_{g}\right),
$$

Where: $A_{t=1,1,2}$ is the attitude of $\mathrm{P} 1$ towards $\mathrm{P} 2$ at time $\mathrm{t}=1 ; \mathrm{A}_{\mathrm{t}=0,1,2}$ is the attitude of $\mathrm{P} 1$ towards $\mathrm{P} 2$ at time $\mathrm{t}=0 ; \mathrm{f}_{\mathrm{a}}=$ function represents the congruity and adaptation effects (both speed and wish intensity to reach congruity); $\mathrm{CA}_{\text {total }}=\sum_{\mathrm{k}} \mathrm{CAc}_{\mathrm{k}^{\prime}, 1}+\sum_{\mathrm{k}}, \mathrm{CAc}_{\mathrm{k}, 2}$, represents the cumulative congruity or incongruity regarding the contributions of each partner; and $\mathrm{Mg}_{\mathrm{g}}$ represents the potential moderation of gender on the adaptation of the congruity function. 
Moreover, regarding the special theory, propositions may be specified further along the lines of a number of diverse dimensions of culture, see the cultural vector presented previously, for example, Hofstede's dimensions such as collectivism/individualism, or cultural distance. As suggested by Brett and Okumura (1998, p.496) "The linkage of goals to self as opposed to the collective and the emphasis on personal needs as opposed to social obligations suggest that individualists should be more self-interested in negotiations than collectivists." This indicates that differences between individualistic and collectivistic cultures are expected to be significant in the context of cross-cultural negotiation interactions.

Below are examples of such propositions.

Proposition 2a: Considering a sequence of interactions and individuals with cultural backgrounds of varying degrees of collectivism/individualism, the wish intensity as well as the speed to reach congruity following incongruent initial evaluations of prospective partners' contributions to an alliance will differ.

Or, using the special theory, refer to Formula (2), and defining $\mathrm{C}_{\mathrm{r}}=\mathrm{C}_{\mathrm{c} / \mathrm{i}}$, we have: $A_{t=1,1,2}=A_{t=0,1,2}+f_{a}\left(C_{\text {total }}, C_{c / i}\right)$

Where: $A_{t=1,1,2}$ is the attitude of $\mathrm{P} 1$ towards $\mathrm{P} 2$ at time $\mathrm{t}=1 ; \mathrm{A}_{\mathrm{t}=0,1,2}$ is the attitude of P1 towards $\mathrm{P} 2$ at time $\mathrm{t}=0 ; \mathrm{f}_{\mathrm{a}}=$ function represents the congruity and adaptation effects (both speed and wish intensity to reach congruity); $\mathrm{CA}_{\mathrm{total}}=\sum_{\mathrm{k}} \mathrm{CAc}_{\mathrm{k}^{\prime}, 1}+\sum_{\mathrm{k}} \mathrm{CAc}_{\mathrm{k}, 2}$, represents the cumulative congruity or incongruity regarding the contributions of each partner; and $\mathrm{C}_{\mathrm{c} / \mathrm{i}}$ represents the potential moderation of the cultural bi-polar dimension of collectivism/individualism on the adaptation of the congruity function. 
Different expectations and procedures dependent on the local cultural environment have been indicated as determining the chances of success of business ventures (Buckley, Clegg, \& Tan, 2006). Thus, considering a general culture-related construct (i.e. cultural distance):

Proposition 2b: Considering a sequence of interactions and individuals with different cultural backgrounds having a non-zero cultural distance, the wish intensity as well as the speed to reach congruity following incongruent initial valuations of prospective partners' contributions to an alliance will differ.

Or using as previously the special theory, refer to formula (2), and defining $\mathrm{C}_{\mathrm{r}}=$ $\mathrm{C}_{\mathrm{C}-\mathrm{D}}$, we have:

$$
\mathrm{A}_{\mathrm{t}=1,1,2}=\mathrm{A}_{\mathrm{t}=0,1,2}+\mathrm{f}_{\mathrm{a}}\left(\mathrm{CA}_{\text {total }}, \mathrm{C}_{\mathrm{C}-\mathrm{D}}\right)
$$

Where: $\mathrm{A}_{\mathrm{t}=1,1,2}$ is the Attitude of $\mathrm{P} 1$ towards $\mathrm{P} 2$ at time $\mathrm{t}=1 ; \mathrm{A}_{\mathrm{t}=0,1,2}$ is the Attitude of $\mathrm{P} 1$ towards $\mathrm{P} 2$ at time $\mathrm{t}=0 ; \mathrm{f}_{\mathrm{a}}=$ function represents the congruity and adaptation effects (both speed and wish intensity to reach congruity); $\mathrm{CA}_{\mathrm{total}}=\sum_{\mathrm{k}} \mathrm{CAc}_{\mathrm{k}^{\prime}, 1}+\sum_{\mathrm{k}}, \mathrm{CAc}_{\mathrm{k}, 2}$, represents the cumulative congruity or incongruity regarding the contributions of each partner; and $\mathrm{C}_{\mathrm{C}-\mathrm{D}}$ represents the potential moderation of the cultural distance on the adaptation of the congruity function.

The impact of discordant mindsets may be illustrated with the case of KKR (Kohlberg Kravis Roberts), the renowned corporate buy-out investor. One of the three founders split-up after over ten years of joint operations due among other factors to "differences between the harddriving business style of the young cousins [i.e., Henry Kravis and his cousin George Roberts] and the quieter approach of their former mentor [Jerome Kohlberg]" (Sender, 2011). 
An evolving mindset has been highlighted as important in todays' world. The implicit implication is that different mindsets coexist in todays' business environment and, as pointed out by Gupta and Govindarajan (2002), they operate differently, some more successfully than others. A proposition addressing this issue is suggested below.

Another dimension, paralleling the idea of mindset, is an executive's personality trait, as illustrated by the case of Wipro, the Indian giant computer services provider and their joint CEOs, Mr Suresh Vaswani and Mr Girish Paranjpe. Explaining their dissimilar approaches and its positive effect we quote Mr Paranjpe: "Since we have different personalities, we find people and clients interact differently with us. So that becomes a good tactic. Some clients respond better to me and others to Suresh [i.e., Mr Suresh Vaswani].” (Leahy, 2008).

We could create propositions to be tested for the application of the special theory regarding mind-sets, which parallels what we proposed previously regarding cultural dimensions, as follows.

Proposition 3: Considering a sequence of interactions and individuals with different mind-sets, initial valuations of prospective partners' contributions as well as the wish intensity and the speed to reach congruity following incongruent initial evaluations of prospective partners' contributions to an alliance will differ.

Or, using as previously the special theory, refer to formula (3), and defining $\mathrm{C}_{\mathrm{r} 1}=$ $\mathrm{C}_{\mathrm{m}-\mathrm{s}}$, we have:

$$
A_{t=1,1,2}=A_{t=0,1,2}+f_{a}\left(C_{\text {total }}, C_{m-s}\right)
$$

Where: $A_{t=1,1,2}$ is the Attitude of P1 towards P2 at time $t=1 ; A_{t=0,1,2}$ is the Attitude of P1 towards $\mathrm{P} 2$ at time $\mathrm{t}=0 ; \mathrm{f}_{\mathrm{a}}=$ function represents the congruity and adaptation effects (both speed and wish intensity to reach congruity); $\mathrm{CA}_{\mathrm{total}}=\sum_{\mathrm{k}} \mathrm{CAc}_{\mathrm{k}, 1}{ }+\sum_{\mathrm{k}}, \mathrm{CAc}_{\mathrm{k}, 2}$, represents the 
cumulative congruity or incongruity regarding the contributions of each partner; and $\mathrm{C}_{\mathrm{m}-\mathrm{s}}$ represents the potential moderation of the differing mind-sets on the adaptation of the congruity function.

The above propositions may generate a number of hypotheses aimed at testing the different theoretical levels (i.e., general theory, special theory, and application of the special theory). We theorize that variations in the context as well as variations regarding the timing and order of the interactions in a sequence may lead to diverse outcomes. Both quantitative and qualitative techniques may be used to test and develop the theory. Regarding the former, simulations of business interactions seem an appropriate research instrument to achieve a better control of the parameters considered (e.g., Brett and Okumura, 1998; Graham et al., 1992). Surveys regarding cross-cultural business interaction practices may also be employed to test the theory under specific circumstances (e.g., Rao \& Schmidt, 1998). The analysis of secondary panel data may provide additional insights particularly in relation to comparisons of two or more country environments and cultures. In issues that concern qualitative techniques, case studies could also be used to detail the micro-dynamic procedures used by practitioners, bringing the theory closer to questions arising from current and novel real-life managerial challenges and empirical solutions (e.g., Buckley, 2002). A multidisciplinary approach could also play an important role in developing this theory, particularly the use of disciplines such as anthropology (Buckley \& Chapman, 1996).

\section{Conclusions}

Based on the principle of congruity, this paper seeks to advance understanding of individualto-individual micro-dynamics of two-party interactions in the final stages of a transnational alliance (TA) formation. More specifically, using the principle of congruity we develop a 
general theory that considers the effect of a mismatch of expectations between prospective partners about the contributions of both partners plus the partners' attitudes towards each other on the likelihood of alliance formation. We also develop a special theory that considers cultural differences as influencing managers' wish to follow the principle of congruity, taking into account both the intensity and speed of adjustment. Finally, we present an application of the special case which reflects the effect of different mind-sets between managers of firms from developed countries (DC) and their counterparts in large emerging markets. Recent studies propose similar paths, particularly on interpersonal interaction (e.g., Lander \& Kooning, 2013). The potential for a successful TA can be significantly influenced by the perceptions and expectations of the principal parties involved, as well as by their attitudes. The reasons why misconceptions arise appear to be related, at least in part, to differences in national culture and business environments.

\subsection{Managerial Relevance}

Our study implies that managers who enter into discussions on the formation of transnational alliances should focus on communicating clearly and explicitly what resources they intend to commit to provide, and what they expect to receive from the arrangement, since this is likely to be a significant source of misunderstanding and potential conflict; this should occur either during the allying process, or once the alliance has been agreed.

This paper also contributes by raising awareness of the importance of managers being cognizant of possible mismatches of expectations during the alliance formation process, and the importance of being better prepared to deal with any potential mismatches. Preemption or early identification of issues that could lead to misunderstandings concerning potential partner contributions can increase the ability of managers to intervene and resolve any mistrust that might arise, through better communication of respective viewpoints and 
objectives, and through the development of joint solutions. Therefore, if areas of high conflict-generation potential can be identified in advance during the informal stages of TA formation, and then evaluated and acted upon early by managers, such misconceptions can be addressed to minimise their effects. The use of checklists and other tools that focus attention on potential sources of misconceptions, such as the contributions expected of a partner, may complement more informal efforts to identify and take steps to mitigate the effects of misunderstandings and conflict, and to promote a self-reinforcing dynamic of mutual trustbuilding.

We propose that an attitude of mutual commitment and trust-building may be accomplished by unilateral or multilateral efforts by the parties involved to understand the standpoint of the other party. In so doing, managers should be able to reach a better understanding of the consequences of their respective demands that might appear, on the surface at least, to be associated with national, 'taken-for-granted', mind-sets. With this in mind, pre-alliance formation discussions with prospective collaborators could follow a step-wise approach, in which (i) the partners identify the contributions they expect to make towards and receive from the other party (perhaps using checklists), (ii) these contributions are ranked or scored by managers according to the relative importance to their firm, and (iii) these rankings are shared between the partners in order to draw attention to where any incongruity of expectation is greatest, and therefore where further dialogue is needed. One possible limitation is that culturally-embedded factors that affect business interactions can be expected to have different speeds of change (Fang, Worm, \& Tung, 2008).

\subsection{Relevance for Policy Formulation}

This approach may be considered by policy-makers when they seek to promote alliances. In this context, a similar use of checklists as suggested above to managers may be helpful in seeking clarity about the respective positions of TA partners. Many governments around the 
world are looking to promote high-technology and high value-added sectors as a key development objective, while emerging economies not only have untapped markets for final products but can also be seen as high-demand markets for novel technologies. It is recommended that mechanisms are established that help to clarify the objectives of companies in these types of sectors regarding the establishment of TAs with foreign firms, particularly among those government agencies charged with promoting international technology transfer through the use of transnational alliances. In addition, the support of managers of small and medium-sized businesses in terms of training and increased awareness about problems that may be caused by incongruities of expectations should assist with efforts to attract foreign investors and new-technology developers to emerging economies. At the same time, the dissemination among emerging economies of innovative products deriving from new product development initiatives in advanced countries could increase the generation of revenue amongst technology-based firms.

\section{Notes}

${ }^{1}$ This approach simplifies the three-level approach adopted in previous studies (e.g., Tannenbaum, 1956). 


\section{References}

Aaker, D. A., \& Keller, K. L. (1990). Consumer evaluations of brand extensions. Journal of Marketing, 54, 27-41.

Abramson, N. R., Lane, H. W., Nagai, H., \& Takagi, H. (1993). A comparison of Canadian and Japanese cognitive styles - implications for management interaction. Journal of International Business Studies, 24, 575-587.

Adair, W. L., Weingart, L., \& Brett, J. (2007). The timing and function of offers in US and Japanese negotiations. Journal of Applied Psychology, 92, 1056-1068.

Adler, N. J., Brahm, R., \& Graham, J. L. (1992). Strategy implementation: A comparison of face-toface negotiations in the People's Republic of China and the United States. Strategic Management Journal, 13, 449-466.

Adler, N. J., Doktor, R., \& Redding, S. G. (1986). From the Atlantic to the Pacific century - crosscultural management reviewed. Journal of Management, 12, 295-318.

Bales, R. F. (1950). Interaction process analysis: A method for the study of groups. Chicago and London: The University of Chicago Press.

Barkema, H. G., \& Vermeulen, F. (1997). What differences in the cultural backgrounds of partners are detrimental for international joint ventures? Journal of International Business Studies, 28, 845-864.

Beamish, P. W. (1987). Joint ventures in LDCs: Partner selection and performance. Management International Review, 27, 23-37.

Bhattacharya, R., Devinney, T. M., \& Pillutla, M. M. (1998). A formal model of trust based on outcomes. Academy of Management Review, 23, 459-472.

Bierly, P. E., III, \& Gallagher, S. (2007). Explaining alliance partner selection: Fit, trust and strategic expediency. Long Range Planning, 40, 134-153.

Blodgett, L. L. (1991). Partner contributions as predictors of equity share in international joint ventures. Journal of International Business Studies, 22, 63-78.

Brady, H. E., \& Sniderman, P. M. (1985). Attitude attribution - a group basis for political reasoning. American Political Science Review, 79, 1061-1078.

Brett, J. M., \& Okumura, T. (1998). Inter- and intracultural negotiation: US and Japanese negotiators. Academy of Management Journal, 41, 495-510.

Buckley, P. J. (2002). Is the international business research agenda running out of steam? Journal of International Business Studies, 33, 365-373.

Buckley, P. J., \& Casson, M. (1988). A theory of cooperation in international business. In F. J. Contractor \& P. Lorange (Eds.), Cooperative Strategies in International Business. Lexington, MA: Lexington Books.

Buckley, P. J., \& Casson, M. (1996). An economic model of international joint venture strategy. Journal of International Business Studies, 27, 849-876.

Buckley, P. J., \& Chapman, M. (1996). Economics and social anthropology - Reconciling differences. Human Relations, 49, 1123-1150.

Buckley, P. J., Clegg, J., \& Tan, H. (2006). Cultural awareness in knowledge transfer to China - The role of guanxi and mianzi. Journal of World Business, 41, 275-288.

Buckley, P. J., \& Strange, R. (2010). The governance of the multinational enterprise: Insights from internalization theory. Journal of Management Studies, 48, 460-470.

Burt, R. S. (1997). The contingent value of social capital. Administrative Science Quarterly, 42, 339365.

Carter, E. E. (1971). Project evaluations and firm decisions. Journal of Management Studies, 8, 253279.

Cavusgil, S. T., Ghauri, P. N., \& Akcal, A. A. (2013). Doing business in emerging markets ( $2^{\text {nd }}$ ed.). London: Sage Publications.

Chen, D., Park, S. H., \& Newburry, W. (2009). Parent contribution and organizational control in international joint ventures. Strategic Management Journal, 30, 1133-1156.

Chen, Y. R., Mannix, E. A., \& Okumura, T. (2003). The importance of who you meet: Effects of selfversus other-concerns among negotiators in the United States, the People's Republic of China, 
and Japan. Journal of Experimental Social Psychology, 39, 1-15.

Chua, J. H., \& Woodward, R. S. (1993). Splitting the firm between the entrepreneur and the venture capitalist with the help of stock-options. Journal of Business Venturing, 8, 43-58.

Chung, J. E., Sternquist, B., \& Chen, Z. Y. (2006). Retailer-buyer supplier relationships: The Japanese difference. Journal of Retailing, 82, 349-355.

Chung, S., Singh, H., \& Lee, K. (2000). Complementarity, status similarity and social capital as drivers of alliance formation. Strategic Management Journal, 21, 1-22.

Cohen, W. M., \& Levinthal, D. A. (1990). Absorptive-capacity - a new perspective on learning and innovation. Administrative Science Quarterly, 35, 128-152.

Coleman, J. S. (1988). Social capital in the creation of human-capital. American Journal of Sociology, 94, S95-S120.

Collet, F., \& Philippe, D. (2014). From Hot Cakes to Cold Feet: A Contingent Perspective on the Relationship between Market Uncertainty and Status Homophily in the Formation of Alliances. Journal of Management Studies, 51, 406-432.

Contractor, F. J. (1985). A generalized theorem for joint-venture and licensing negotiations. Journal of International Business Studies, 16, 23-50.

Corfman, K. P., \& Lehmann, D. R. (1993). The importance of others welfare in evaluating bargaining outcomes. Journal of Consumer Research, 20, 124-137.

Das, T. K., \& Teng, B. S. (2002). Alliance constellations: A social exchange perspective. Academy of Management Review, 27, 445-456.

De Dreu, C. K. W., Weingart, L. R., \& Kwon, S. (2000). Influence of social motives on integrative negotiation: A meta-analytic review and test of two theories. Journal of Personality and Social Psychology, 78, 889-905.

De Mattos, C., Burgess, T. F., \& Shaw, N. E. (2013). The impact of R\&D-specific factors on the attractiveness of small- and medium-sized enterprises as partners vis-à-vis alliance formation in large emerging economies. $R \& D$ Management, 43, 1-20.

De Mattos, C., Sanderson, S., \& Ghauri, P. (2002). Negotiating alliances in emerging markets-Do partners' contributions matter? Thunderbird International Business Review, 44, 701-728.

Delios, A., \& Beamish, P. W. (2004). Joint Venture Performance Revisited: Japanese Foreign Subsidiaries Worldwide1. Management International Review, 44, 69.

Dhanaraj, C., Lyles, M. A., Steensma, H. K., \& Tihanyi, L. (2004). Managing tacit and explicit knowledge transfer in IJVs: The role of relational embeddedness and the impact on performance. Journal of International Business Studies, 35, 428-442.

Dinello, N. E., \& Shaoguang, W. (2009). China, India and beyond: development drivers and limitations. In Global development network series (pp. xxxv, 254). Cheltenham, UK ; Northampton, MA: Edward Elgar.

Doney, P. M., Cannon, J. P., \& Mullen, M. R. (1998). Understanding the influence of national culture on the development of trust. Academy of Management Review, 23, 601-620.

Dong, H., Buckley, P. J., \& Mirza, H. (1997). International joint ventures in China from a managerial perspective: A comparison between different sources of investment. In G. Chryssochoidis, C. Millar \& J. Clegg (Eds.), Internationalisation Strategies. New York: St.Martin.

Dong, L., \& Glaister, K. W. (2006). Motives and partner selection criteria in international strategic alliances: Perspectives of Chinese firms. International Business Review, 15, 577-600.

Eichengreen, B. J., Gupta, P., \& Kumar, R. (2010). Emerging giants: China and India in the world economy. In (pp. xxxi, 368). Oxford: Oxford University Press.

Erden, D. (1997). Stability and satisfaction in cooperative FDI: Partnerships in Turkey. In B. P.W. (Ed.), Cooperative Strategies: European perspectives (pp. 158-183).

Fagre, N., \& Wells, L. T. (1982). Bargaining power of multinationals and host governments. Journal of International Business Studies, 13, 9-23.

Fang, T., Worm, V., \& Tung, R. L. (2008). Changing success and failure factors in business negotiations with the PRC. International Business Review, 17, 159-169.

Farrell, G. \& Sender, H. (2009) 'Lynched at Merrill', Financial Times, January 26.

Ferrin, D. L., Bligh, M. C., \& Kohles, J. C. (2008). It takes two to tango: An interdependence analysis of the spiraling of perceived trustworthiness and cooperation in interpersonal and intergroup relationships. Organizational Behavior and Human Decision Processes, 107, 161-178. 
Fey, C. F., \& Beamish, P. W. (2000). Joint venture conflict: the case of Russian international joint ventures. International Business Review, 9, 139-162.

Filatotchev, I., Liu, X., Buck, T., \& Wright, M. (2009). The export orientation and export performance of high-technology SMEs in emerging markets: The effects of knowledge transfer by returnee entrepreneurs. Journal of International Business Studies, 40, 1005-1021.

Fornell, C., Lorange, P., \& Roos, J. (1990). The cooperative venture formation process - a latent variable structural modeling approach. Management Science, 36, 1246-1255.

Fulmer, C. A., \& Gelfand, M. J. (2012). At what level (and in whom) we trust: Trust across multiple organizational levels. Journal of Management, 38, 1167-1230.

Gelfand, M. J., Major, V. S., Raver, J. L., Nishii, L. H., \& O'Brien, K. (2006). Negotiating relationally: The dynamics of the relational self in negotiations. Academy of Management Review, 31, 427-451.

Geringer, J. M. (1991). Strategic determinants of partner selection criteria in international joint ventures. Journal of International Business Studies, 22, 41-62.

Glaister, K. W., \& Buckley, P. J. (1996). Strategic motives for international alliance formation. Journal of Management Studies, 33, 301-332.

Glaister, K. W., \& Buckley, P. J. (1997). Task-related and partner-related selection criteria in UK international joint ventures. British Journal of Management, 8, 199-222.

Graham, J. L. (1985). The influence of culture on the process of business negotiations: An exploratory study. Journal of International Business Studies, 16, 81-96.

Graham, J. L., Evenko, L. I., \& Rajan, M. N. (1992). An empirical-comparison of Soviet and American business negotiations. Journal of International Business Studies, 23, 387-418.

Grant, R. M., \& Baden-Fuller, C. (2004). A knowledge accessing theory of strategic alliances. Journal of Management Studies, 41, 61-84.

Gulati, R. (1995a). Social structure and alliance formation patterns: A longitudinal analysis. Administrative Science Quarterly, 40, 619-652.

Gulati, R. (1995b). Does familiarity breed trust - the implications of repeated ties for contractual choice in alliances. Academy of Management Journal, 38, 85-112.

Gulati, R., Lavie, D., \& Singh, H. (2009). The nature of partnering experience and the gains from alliances. Strategic Management Journal, 30, 1213-1233.

Gupta, A. K., \& Govindarajan, V. (2002). Cultivating a global mindset. The Academy of Management Executive, 16, 116.

Gupta, P., Hasan, R., \& Kumar, U. (2010). What constrains Indian manufacturing. In B. J. Eichengreen, P. Gupta \& R. Kumar (Eds.), Emerging giants: China and India in the world economy. Oxford: Oxford University Press.

Hagedoorn, J. (2006). Understanding the cross-level embeddedness of interfirm partnership formation. Academy of Management Review, 31, 670-680.

Hamel, G. (1991). Competition for competence and inter-partner learning within international strategic alliances. Strategic Management Journal, 12, 83-103.

Harrigan, K. R. (1988). Joint ventures and competitive strategy. Strategic Management Journal, 9, $141-158$

Hennart, J.-F. (1988). A transaction costs theory of equity joint ventures. Strategic Management Journal, 9, 361-374.

Hofstede, G. (1980). Culture's consequences: International differences in work related values. Beverly Hills: Sage Publications.

Inkpen, A. C., \& Currall, S. C. (2004). The coevolution of trust, control, and learning in joint ventures. Organization Science, 15, 586-599.

Inkpen, A. C., \& Tsang, E. W. K. (2005). Social capital, networks, and knowledge transfer. Academy of Management Review, 30, 146-165.

Jap, S., Robertson, D. C., \& Hamilton, R. (2011). The dark side of rapport: Agent misbehavior faceto-face and online. Management Science, 57, 1610-1622.

Jones, G. R., \& George, J. M. (1998). The experience and evolution of trust: Implications for cooperation and teamwork. Academy of Management Review, 23, 531-546.

Kale, P., \& Singh, H. (2009). Managing strategic alliances: What do we know now, and where do we go from here? The Academy of Management Perspectives, 23, 45-62. 
Kale, P., Singh, H., \& Perlmutter, H. (2000). Learning and protection of proprietary assets in strategic alliances: Building relational capital. Strategic Management Journal, 21, 217-237.

Katz, M. L. (1986). An analysis of cooperative research-and-development. Rand Journal of Economics, 17, 527-543.

Kim, K. I., Park, H. J., \& Suzuki, N. (1990). Reward allocations in the United-States, Japan, and Korea - a comparison of individualistic and collectivistic cultures. Academy of Management Journal, 33, 188-198.

Kim, P. H., Dirks, K. T., \& Cooper, C. D. (2009). The repair of trust: A dynamic bilateral perspective and multilevel conceptualization. Academy of Management Review, 34, 401-422.

Kirkpatrick, S. A., \& McLemore, L. (1977). Perceptual and affective components of legislative norms - social-psychological analysis of congruity. Journal of Politics, 39, 685-711.

Kogut, B. (1988). Joint ventures - theoretical and empirical perspectives. Strategic Management Journal, 9, 319-332.

Kogut, B. (1991). Joint ventures and the option to expand and acquire. Management Science, 37, 1933.

Koka, B. R., \& Prescott, J. E. (2002). Strategic alliances as social capital: A multidimensional view. Strategic Management Journal, 23, 795-816.

Kotabe, M., Parente, R., \& Murray, J. Y. (2007). Antecedents and outcomes of modular production in the Brazilian automobile industry: A grounded theory approach. Journal of International Business Studies, 38, 84-106.

Kotabe, M., Teegen, H., Aulakh, P. S., Coutinho de Arruda, M. C., Santillán-Salgado, R. J., \& Greene, W. (2000). Strategic alliances in emerging Latin America: a view from Brazilian, Chilean, and Mexican companies. Journal of World Business, 35, 114-132.

Lander, M. W., \& Kooning, L. (2013). Boarding the aircraft: Trust development amongst negotiators of a complex merger. Journal of Management Studies, 50, 1-30.

Leahy, J. (2008) 'Management by the 'power of two", Financial Times, September 22.

Lee, K., Yang, G., \& Graham, J. L. (2006). Tension and trust in international business negotiations: American executives negotiating with Chinese executives. Journal of International Business Studies, 37, 623-641.

Lee, S. H., Shenkar, O., \& Li, J. T. (2008). Cultural distance, investment flow, and control in crossborder cooperation. Strategic Management Journal, 29, 1117-1125.

Liu, L. A., Chua, C. H., \& Stahl, G. K. (2010). Quality of communication experience: Definition, measurement, and implications for intercultural negotiations. Journal of Applied Psychology, 95, 469-487.

Liu, W., Friedman, R., \& Hong, Y.-Y. (2012). Culture and accountability in negotiation: Recognizing the importance of in-group relations. Organizational Behavior and Human Decision Processes, 117, 221-234.

Lu, Y., Zhou, L., Bruton, G., \& Li, W. (2010). Capabilities as a mediator linking resources and the international performance of entrepreneurial firms in an emerging economy. Journal of International Business Studies, 41, 419-436.

Lunnan, R., \& Haugland, S. (2008). Predicting and measuring alliance performance: a multidimensional analysis. Strategic Management Journal, 29, 545-556.

Malhotra, D. (2013). How to negotiate with VCs. Harvard Business Review, 91, 84-90.

Malhotra, D., \& Gino, F. (2011). The pursuit of power corrupts: How investing in outside options motivates opportunism in relationships. Administrative Science Quarterly, 56, 559-592.

Marcus, J., \& Le, H. (2013). Interactive effects of levels of individualism-collectivism on cooperation: A meta-analysis. Journal of Organizational Behavior, 34, 813-834.

Marino, L., Strandholm, K., Steensma, H. K., \& Weaver, K. M. (2002). The moderating effect of national culture on the relationship between entrepreneurial orientation and strategic alliance portfolio extensiveness. Entrepreneurship: Theory \& Practice, 26, 145-160.

Marshall, R. S., \& Boush, D. M. (2001). Dynamic decision-making: A cross-cultural comparison of US and Peruvian export managers. Journal of International Business Studies, 32, 873-893.

Mayer, R. C., Davis, J. H., \& Schoorman, F. D. (1995). An integrative model of organizational trust. Academy of Management Review, 20, 709-734.

McDermott, G. A., \& Corredoira, R. A. (2010). Network composition, collaborative ties, and 
upgrading in emerging-market firms: Lessons from the Argentine autoparts sector. Journal of International Business Studies, 41, 308-329.

McPherson, M., Smith-Lovin, L., \& Cook, J. M. (2001). Birds of a feather: Homophily in social networks. Annual Review of Sociology, 27, 415-444.

McKnight, D. H., Cummings, L. L., \& Chervany, N. L. (1998). Initial trust formation in new organizational relationships. Academy of Management Review, 23, 473-490.

Meyer, K., Estrin, S., Bhaumik, S., \& Peng, M. (2009). Institutions, resources, and entry strategies in emerging economies. Strategic Management Journal, 30, 61-80.

Molinsky, A. (2007). Cross-cultural code-switching: The psychological challenges of adapting behavior in foreign cultural interactions. Academy of Management Review, 32, 622-640.

Mowery, D. C., Oxley, J. E., \& Silverman, B. S. (1998). Technological overlap and interfirm cooperation: implications for the resource-based view of the firm. Research Policy, 27, 507523.

Muller, A., \& Kolk, A. (2010). Extrinsic and intrinsic drivers of corporate social performance: Evidence from foreign and domestic firms in Mexico. Journal of Management Studies, 47, 126.

Murray, J. Y., Kotabe, M., \& Zhou, J. N. (2005). Strategic alliance-based sourcing and market performance: evidence from foreign firms operating in China. Journal of International Business Studies, 36, 187-208.

NIC. (2008). Global trends 2025: A transformed world: NIC, National Intelligence Council.

Olshavsky, R. W., \& Miller, J. A. (1972). Consumer expectations, product performance, and perceived product quality. Journal of Marketing Research, 9, 19-21.

O'Neill, J., \& Stupnytska, A. (2009). The long-term outlook for the BRICs and N-11 post crisis. In Global Economics Paper No.192: Goldman Sachs.

Osgood, C. E., \& Tannenbaum, P. H. (1955). The principle of congruity in the prediction of attitude change. Psychological Review, 62, 42-55.

Parkhe, A. (1993). Partner nationality and the structure-performance relationship in strategic alliances. Organization Science, 4, 301-304.

Perkins, A. W., \& Forehand, M. R. (2012). Implicit self-referencing: The effect of nonvolitional selfassociation on brand and product attitude. Journal of Consumer Research, 39, 142-156.

Pfeffer, J. (1972). Merger as a response to organizational interdependence. Administrative Science Quarterly, 17, 382-394.

Pfeffer, J., \& Nowak, P. (1976). Joint ventures and interorganizational interdependence. Administrative Science Quarterly, 21, 398-418.

Podolny, J. M. (1993). A status-based model of market competition. American Journal of Sociology, 98, 829-872.

Podolny, J. M. (1994). Market uncertainty and the social character of economic exchange. Administrative Science Quarterly, 39, 458-483.

Portes, A. (1998). Social Capital: Its origins and applications in modern sociology. Annual Review of Sociology, 24, 1-24.

Ramamurti, R., \& Singh, J. V. (2009). Emerging multinationals from emerging markets. Cambridge ; New York: Cambridge University Press.

Rao, A., \& Schmidt, S. M. (1998). A behavioral perspective on negotiating international alliance. Journal of International Business Studies, 29, 665-693.

Raveed, S. R., \& Renforth, W. (1983). State enterprise-multinational corporation joint ventures: How well do they meet both partners' needs? Management International Review, 23, 47-57.

Redding, S. G. (1980). Cognition as an aspect of culture and its relation to management processes - an exploratory view of the Chinese case. Journal of Management Studies, 17, 127-148.

Ring, P. S., \& Van de Ven, A. H. (1992). Structuring cooperative relatioships between organizations. Strategic Management Journal, 13, 483-498.

Sender, H. (2011) 'Lunch with the FT: Henry Kravis and George Roberts', November 18.

Salciuviene, L., Ghauri, P. N., Streder, R. S., \& De Mattos, C. (2010). Do brand names in a foreign language lead to different brand perceptions? Journal of Marketing Management, 26, 10371056.

Santos, J. (2007). Strategy lessons from left field. Harvard Business Review, 85, $20-21$. 
Seale, D. A., Arend, R. J., \& Phelan, S. (2006). Modeling alliance activity: Opportunity cost effects and manipulations in an iterated prisoner's dilemma with exit option. Organizational Behavior and Human Decision Processes, 100, 60-75.

Shapiro, M. J. (1969). Rational political man - synthesis of economic and social-psychological perspectives. American Political Science Review, 63, 1106-1119.

Shipilov, A., \& Li, S. (2008). Can You Have Your Cake and Eat It Too? Structural Holes' Influence on Status Accumulation and Market Performance in Collaborative Networks. Administrative Science Quarterly, 53, 73.

Shipilov, A. V., Li, S. X., \& Greve, H. R. (2011). The Prince and the Pauper: Search and Brokerage in the Initiation of Status-Heterophilous Ties. Organization Science, 22, 1418-1434.

Siqueira, A., \& Bruton, G. (2010). High-technology entrepreneurship in emerging economies: Firm informality and contextualization of resource-based theory. IEEE Transactions on Engineering Management, 57, 39-50.

Song, F. (2009). Intergroup trust and reciprocity in strategic interactions: Effects of group decisionmaking mechanisms. Organizational Behavior and Human Decision Processes, 108, 164173.

Srivastava, J., \& Chakravarti, D. (2009). Channel negotiations with information asymmetries: Contingent influences of communication and trustworthiness reputations. Journal of Marketing Research, 46, 557-572.

Stopford, J. M., \& Wells, L. T. (1972). Managing the multinational enterprise: organization of the firm and ownership of the subsidiaries. New York: Basic Books.

Stuart, T. E. (1998). Network positions and propensities to collaborate: An investigation of strategic alliance formation in a high-technology industry. Administrative Science Quarterly, 43, 668698.

Tannenbaum, P. H. (1956). Initial attitude toward source and concept as factors in attitude-change through communication. Public Opinion Quarterly, 20, 413-425.

Tinsley, C. H. (2001). How negotiators get to yes: Predicting the constellation of strategies used across cultures to negotiate conflict. Journal of Applied Psychology, 86, 583-593.

Tinsley, C. H., \& Pillutla, M. M. (1998). Negotiating in the United States and Hong Kong. Journal of International Business Studies, 29, 711-727.

Trevino, L. J., \& Mixon Jr., F. G. (2004). Strategic factors affecting foreign direct investment decisions by multi-national enterprises in Latin America. Journal of World Business, 39, 233243.

UNCTAD. (2009). World investment report 2009: Transnational corporations, agricultural production and development. New York and Geneva: United Nations.

UNCTAD. (2010). World investment report 2010: Investing in a low-carbon economy. New York and Geneva: United Nations.

Van de Ven, A. H. (1976). On the nature, formation, and maintenance of relations among organizations. Academy of Management Review, 1, 24-36.

Waldmeir, P. (2011) ' 'Voluptuous' Volvo debuts in China'. Financial Times, April 20.

Wassmer, U., Dussauge, P., \& Planellas, M. (2010). How to manage alliances better than one at a time. MIT Sloan Management Review, 51, 77-84.

Wasti, S. (2008). Trust in buyer-supplier relations: the case of the Turkish automotive industry. Journal of International Business Studies, 39, 118-131.

Weingartner, H. M., \& Gavish, B. (1993). How to settle an estate. Management Science, 39, 588-601.

Williamson, O. E. (1979). Transaction-cost economics: The governance of contractual relations. Journal of Law and Economics, 22, 233-261.

Williamson, O. E. (1991). Comparative economic organization: The analysis of discrete structural alternatives. Administrative Science Quarterly, 36, 269-296.

Wilson, D., Kelston, A. L., \& Ahmed, S. (2010). Is this the 'BRICs decade'? : Goldman Sachs.

World Bank. (2010). Doing business 2010: World Bank.

Wright, M., Filatotchev, I., Buck, T., \& Bishop, K. (2002). Foreign partners in the former Soviet Union. Journal of World Business, 37, 165-179.

Yan, A., \& Gray, B. (2001). Antecedents and effects of parent control in international joint ventures. Journal of Management Studies, 38, 393-416. 
Zaheer, A., McEvily, B., \& Perrone, V. (1998). Does trust matter? Exploring the effects of interorganizational and interpersonal trust on performance. Organization Science, 9, 141-159.

Zaheer, A., \& Venkatraman, N. (1995). Relational governance as an interorganizational strategy: An empirical test of the role of trust in economic exchange. Strategic Management Journal, 16, 373-392.

Zhang, J. (2010). The Persuasiveness of Individualistic and Collectivistic Advertising Appeals Among Chinese Generation-X Consumers. Journal of Advertising, 39, 69-80. 
Table 1

Possible Congruence of Evaluations in a Two Level Model

\begin{tabular}{|l|c|c|c|}
\hline $\mathrm{CA}_{1,2, \mathrm{C} 1,2}$ & \multicolumn{3}{|c|}{$\mathrm{A}_{2, \mathrm{C} 1,2}{ }^{\mathrm{a}}$} \\
\hline \multirow{3}{*}{$\mathrm{A}_{1, \mathrm{C} 1,2} \mathrm{~b}$} & \multicolumn{3}{|c|}{} \\
\cline { 2 - 4 } & + & + & 0 \\
\cline { 2 - 4 } & 0 & $0^{\mathrm{c}}$ & -1 \\
\hline
\end{tabular}

${ }^{*} \mathrm{a} 2$ attitude towards $\mathrm{C}_{1,2},{ }^{\mathrm{b}} \mathrm{P} 1$ attitude towards $\mathrm{C}_{1,2}$,

c ' 0 ' = congruous, ' -1 ' = incongruous 
Figure 1:

Influence of Congruity of Evaluations / Expectations regarding Partner Contributions and Likelihood of Alliance Formation

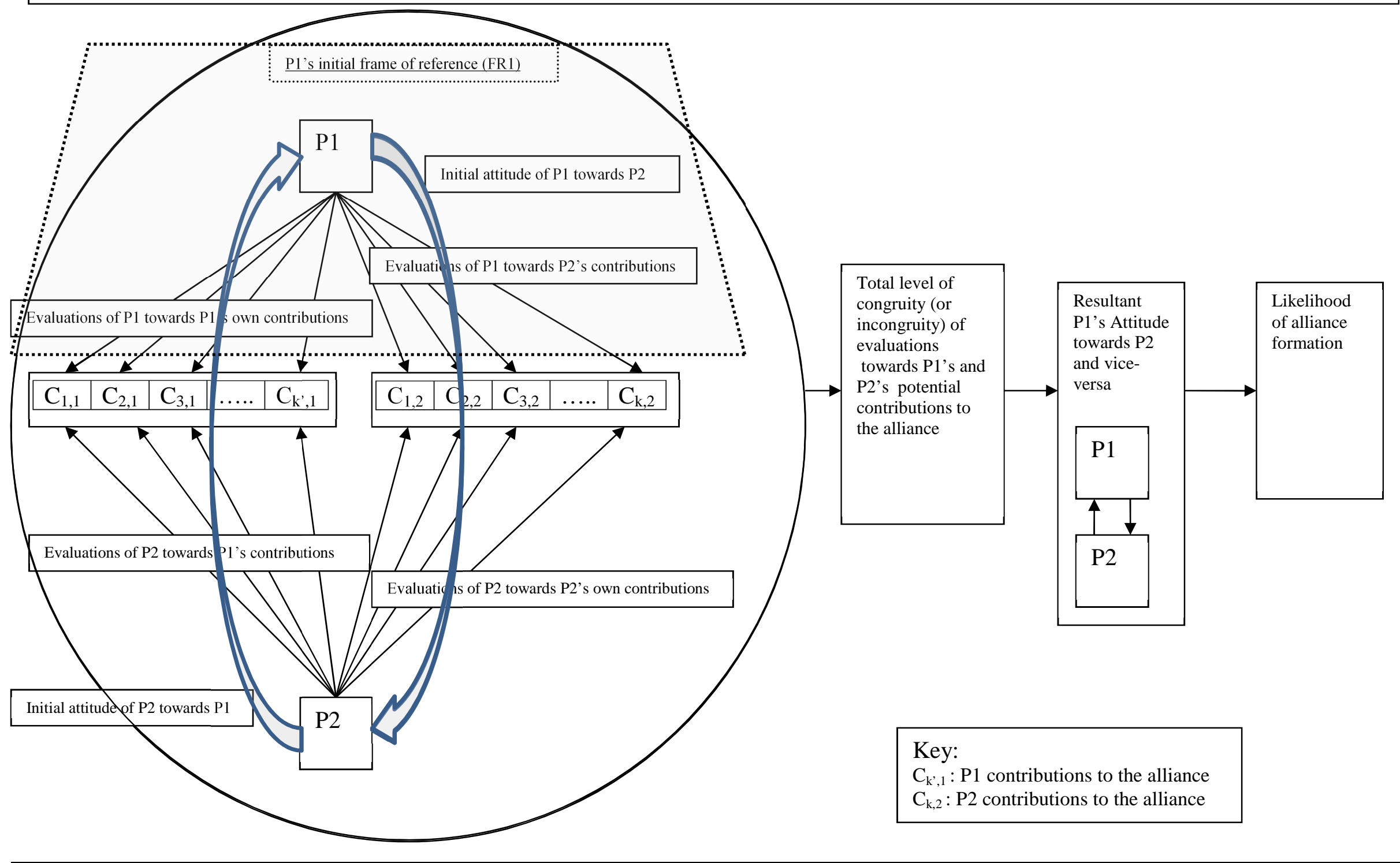


Figure 2

Change in attitude of $\mathrm{P} 1$ towards $\mathrm{P} 2$, following an incongruent evaluation of $\mathrm{P} 2$ regarding $\mathrm{P} 2$ 's own potential contribution $1\left(\mathrm{C}_{1,2}\right)$

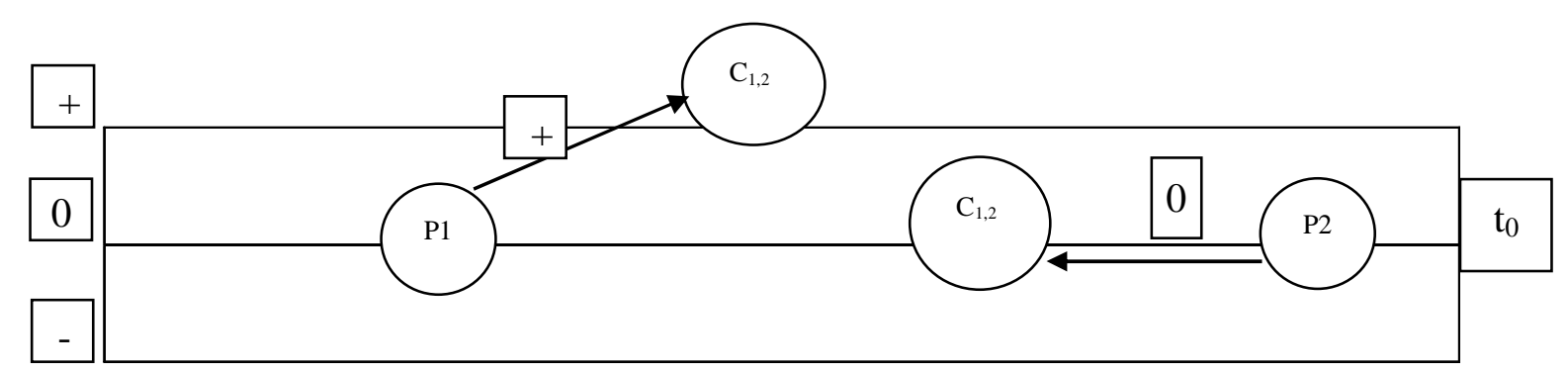

Initial setting ( $\mathbf{t = 0} \mathbf{0})$ : Attitude of $\mathrm{P} 1$ towards $\mathrm{P} 2$ is neutral, Attitude of $\mathrm{P} 1$ towards $\mathrm{C}_{1,2}$ is positive, Attitude of $\mathrm{P} 2$ towards $\mathrm{C}_{1,2}$ is neutral.

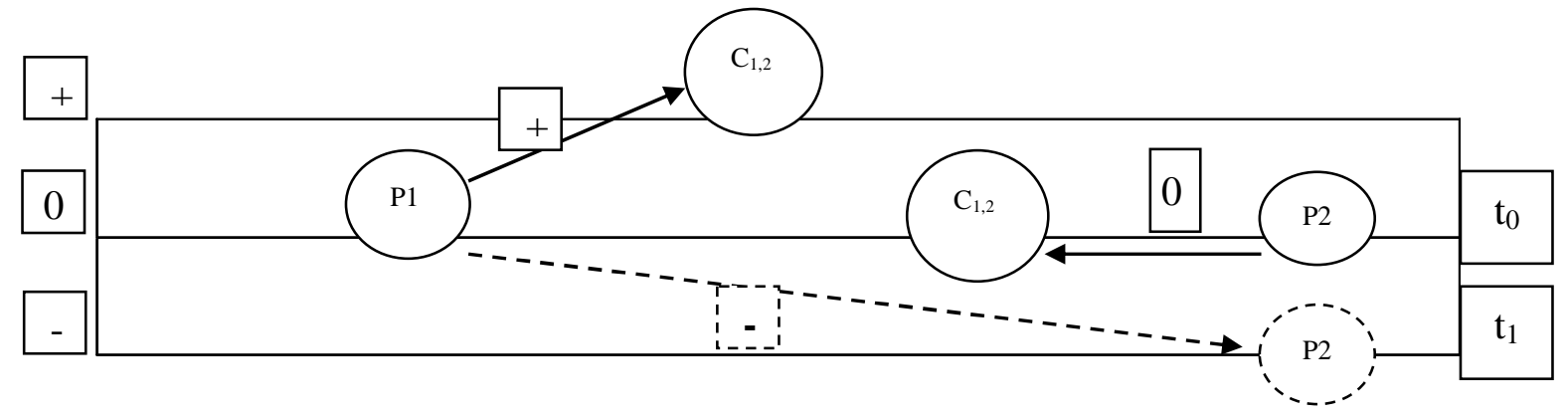

Subsequent setting ( $\mathbf{t = 1})$ : Attitude of P1 towards P2 becomes negative following the principle of congruity 